\title{
SATUAN LINGUAL PENGUNGKAP KEARIFAN LOKAL DALAM PELESTARIAN LINGKUNGAN
}

\author{
Hari Bakti Mardikantoro
}

Fakultas Bahasa dan Seni, Universitas Negeri Semarang

\begin{abstract}
This study aims to reveal the type and the function of linguistic units as the proof of the local wisdom in preserving environment towards society of Javanese Talk. The data on the study are gathered and analyzed based on two procedures; they are the analysis on the process of collecting data and the analysis after the data are collected. The result of the study shows that the type of linguistic units consist of word, phrase, sentence, and expression. Meanwhile, those linguistic units function in expressing local wisdom such as in giving name, commanding/advising, praying, and teaching sesorah values.
\end{abstract}

Keywords: lingual unit, lokal wisdom, preserving environment

\begin{abstract}
Abstrak: Penelitian ini bertujuan memerikan dan menjelaskan pemakaian bentukbentuk dan fungsi satuan lingual sebagai pengungkap kearifan lokal dalam melestarikan lingkungan pada masyarakat tutur bahasa Jawa di Jawa Tengah. Data dalam penelitian kualitatif ini dijaring dengan menggunakan metode simak. Analisis data dilakukan melalui dua prosedur, yaitu analisis selama proses pengumpulan data dan analisis setelah pengumpulan data. Hasil penelitian menunjukkan sebagai berikut. Pertama, bentuk-bentuk satuan lingual pengungkap kearifan lokal meliputi kata, frasa, kalimat, dan wacana. Kedua, fungsi-fungsi satuan lingual pengungkap kearifan lokal meliputi (1) memberi nama, (2) memerintah/menasihati, (3) memanjatkan doa, dan (4) ajaran berbentuk sesorah.
\end{abstract}

Kata kunci: satuan lingual, kearifan lokal, pelestarian lingkungan.

Bahasa adalah produk budaya dan sekaligus wadah penyampai kebudayaan dari masyarakat bahasa yang bersangkutan. Dalam studi kebudayaan, bahasa ditempatkan sebagai sebuah unsur penting selain unsur-unsur lain, seperti sistem pengetahuan, mata pencaharian, adat istiadat, kesenian, dan sistem peralatan hidup. Bahasa dapat dikategorikan sebagai unsur kebudayaan yang berbentuk nonmaterial selain nilai, norma, dan kepercayaan (Liliweri, 2002:151). Bahkan Mahsun (2005:81) menyatakan bahwa bahasa merupakan salah satu budaya manusia yang sangat penting. Melalui bahasa, manusia tidak hanya mengekspresikan pikirannya, tetapi juga menafsirkan dan mengonseptualisasikan dunia yang melingkupinya. 
Dengan kata lain, dalam bahasa terwadahi bagaimana manusia berelasi tidak hanya dengan alam, tetapi juga dengan Sang Pencipta alam semesta itu sendiri.

Peran bahasa sangat dominan dalam kehidupan manusia karena bahasa tidak hanya menjadi bagian dari kebudayaan manusia, tetapi juga menjadi penentu perkembangan kebudayaannya. Bahasa menempati posisi sangat sentral dalam kehidupan manusia karena bahasa mempunyai aspek majemuk terutama meliputi aspek biologis, psikologis, sosial, dan kultural.

Salah satu bukti kemajemukan bahasa adalah fenomena digunakannya bahasa sebagai alat pengungkap hubungan antara manusia dengan alam sekitarnya. Bahasa dalam penggunaannya oleh masyarakat penutur direkam dari sumber-sumber pertuturan dan persuratan yang hidup di sekitar kita. Para penutur dan guyub tutur bahasa apa pun pasti mengenal, menguasai, dan menggunakan perangkat lingual yang berkaitan dengan lingkungannya, baik lingkungan sosial maupun lingkungan alam. Dalam perspektif antropologi kognitif, seperangkat leksikon yang digunakan merupakan objek, peristiwa, dan tanda aktivitas yang penting di lingkungannya (Casson, 1981).

Dalam banyak hal, apa yang dipikirkan atau dirasakan oleh masyarakat selalu diwujudkan dengan bahasa. Oleh karena itu, budaya suatu masyarakat tutur selalu mewarnai bahasa yang digunakan. Demikian pula, apa yang dipikirkan, dirasakan, dan dilakukan manusia terhadap lingkungannya akan tercermin dalam bahasa yang digunakan. Orang yang hidup di daerah pesisir mempunyai budaya yang berbeda dengan orang yang terbiasa hidup di daerah pegunungan. Kebiasaan hidup dan pola pikir mereka tentu berbeda. Konsekuensi logis dari itu semua, bentuk-bentuk bahasa yang digunakan juga berbeda untuk konsep yang sama.

Masyarakat Jawa mempunyai kearifan lokal dalam menyikapi kehidupan sehari-hari, Kearifan lokal merupakan sebuah pilar pemikiran yang didasarkan pada watak tradisi (Endraswara, 2010:211). Oleh karena orang Jawa tidak sekadar mengembangkan pemikiran dalam hidup, kearifan lokal tersebut telah berbaur dengan rasa. Pikiran dan rasa Jawa itulah yang bercampur sehingga membuat orang Jawa lebih bijak. Bijak dalam melaksanakan kehidupan sehari-hari, termasuk dalam menjaga lingkungannya. Bagi masyarakat Jawa, lingkungan adalah manifestasi anugerah dari Sang Pencipta. Oleh karena itu, lingkungan harus dijaga. Masyarakat Jawa kental dengan kearifan lokal dalam menjaga lingkungan. Kearifan lokal tersebut akan tercermin dalam perilaku bertindak dan berbahasa. Oleh karena itu, dalam masyarakat Jawa dikenal tuturan-tuturan yang mencerminkan kearifan lokal, salah satunya tentang bagaimana menjaga keharmonisan hubungan antara masyarakat dan lingkungannya.

Penelitian ini memerikan dan menjelaskan pemakaian satuan-satuan lingual pengungkap kearifan lokal dalam melestarikan lingkungan oleh masyarakat tutur bahasa Jawa di Jawa Tengah. Berdasarkan konteks yang telah diuraikan tersebut, ada dua tujuan yang diungkap dalam penelitian ini, yakni (1) memerikan dan menjelaskan bentuk satuan-satuan lingual sebagai pengungkap kearifan lokal dalam melestarikan lingkungan dan (2) memerikan dan menjelaskan fungsi satuan-satuan lingual sebagai pengungkap kearifan lokal dalam melestarikan lingkungan.

\section{METODE}

Masalah bahasa sebagai pengungkap pandangan hidup suatu masyarakat sering diasumsikan muncul sebagai akibat adanya kenyataan bahwa bahasa tidak bisa dipisahkan 
dari fakta sosial budaya masyarakat pendukungnya. Oleh karena itu, pengkajian masalah ini akan menggunakan orientasi teoretis linguistik struktural, sosiolinguistik, dan etnolinguistik. Linguistik struktural digunakan karena kearifan lokal dalam menjaga kelestarian lingkungan diwujudkan dalam satuan-satuan lingual berupa kata, frasa, kalimat atau wacana. Teori sosiolinguistik digunakan karena satuan-satuan lingual ini dipakai oleh masyarakat tutur bahasa Jawa sehingga faktor sosial masyarakat dipertimbangkan. Teori-teori etnolinguistik digunakan karena satuan-satuan lingual yang akan diungkap dalam penelitian ini berkaitan dengan faktor budaya masyarakat Jawa sebagai pengungkap pandangan hidup mereka tentang lingkungan tempat tinggalnya. Masyarakat Jawa pada umumnya masih memiliki sifat tradisional yang sangat kuat. Segala aspek kehidupannya selalu berhubungan dengan lingkungan sekitarnya. Apalagi masyarakat Jawa merupakan masyarakat agraris sehingga tidak mengherankan jika kehidupannya sangat tergantung pada alam sekitarnya. Oleh karena itu, masyarakat Jawa mempunyai kearifan-kearifan lokal dalam menjaga dan melestarikan lingkungan.

Data penelitian ini berupa kata, frasa, kalimat, dan penggalan wacana yang diduga sebagai pengungkap kearifan lokal dalam melestarikan lingkungan pada masyarakat tutur bahasa Jawa di Jawa Tengah. Ada dua macam data dalam penelitian ini, yakni data sekunder dan data primer. Dengan demikian, ada dua jenis instrumen yang digunakan dalam pengumpulan data. Instrumen pertama berupa lembar pengamatan penggunaan satuansatuan lingual yang digunakan untuk mengungkapkan kearifan lokal mengenai pelestarian lingkungan. Lembar pengamatan tersebut berupa kartu data pengamatan. Adapun instrumen kedua berupa pedoman wawancara. Dengan pedoman wawancara tersebut akan diungkap data sekunder mengenai satuan-satuan lingual yang digunakan serta fungsi satuan-satuan lingual tersebut.

Data dalam penelitian ini dijaring dengan menggunakan metode simak dengan menerapkan teknik sadap sebagai teknik dasarnya dan diteruskan dengan teknik lanjutan yang berupa teknik simak libat cakap, tekik simak bebas libat cakap, teknik rekam, dan teknik catat (Sudaryanto, 1993:133). Dengan demikian, dapat dikatakan bahwa penjaringan data dilakukan dengan metode observasi-partisipatif. Agar proses pengumpulan data dapat berlangsung dengan baik, peneliti juga menggunakan bantuan tape recorder. Di samping itu, peneliti juga menerapkan metode wawancara terutama untuk menggali data mengenai fungsi satuan-satuan lingual sebagai pengungkap kearifan lokal berkaitan dengan pelestarian lingkungan yang digunakan oleh masyarakat tutur Jawa di Jawa Tengah.

Wujud data penelitian ini berupa kata, frasa, kalimat, dan penggalan wacana yang diduga digunakan oleh masyarakat tutur bahasa Jawa di Jawa Tengah untuk mengungkapkan kearifan lokal mengenai pelestarian lingkungan. Adapun sumber datanya berupa wacanawacana yang diduga digunakan oleh masyarakat tutur bahasa Jawa di Jawa Tengah untuk mengungkapkan kearifan lokal mengenai pelestarian lingkungan. Masyarakat tutur bahasa Jawa yang dimaksud dalam penelitian ini adalah masyarakat tutur bahasa Jawa yang tinggal di Jawa Tengah. Namun tidak semua masyarakat tutur bahasa Jawa di Jawa Tengah dipakai sebagai sumber data. Peneliti memilih sumber data masyarakat tutur bahasa Jawa yang tinggal di Kabupaten Blora, Kabupaten Magelang, Kabupaten Semarang, dan Kabupaten Tegal. Pemilihan lokasi didasarkan atas pertimbangan bahkan keempat daerah tersebut mewakili Jawa Tengah bagian timur, barat, utara, dan selatan.

Analisis data dalam penelitian ini lazimnya dilakukan melalui dua prosedur, yaitu (1) analisis selama proses pengumpulan data dan (2) analisis setelah pengumpulan data (Miles dan Huberman 1992:21 - 25). Prosedur pertama dilakukan dengan langkah (a) reduksi data, 
yaitu melakukan identifikasi satuan lingual bahasa Jawa di Jawa Tengah; (b) sajian data dengan matriks; dan (c) pengambilan simpulan/verifikasi yang sifatnya tentatif, baik dengan triangulasi data maupun dengan triangulasi teknik pengambilan data. Prosedur kedua dilakukan dengan langkah (a) transkripsi fonetis data hasil rekaman, (b) pengelompokan atau klasifikasi data dari rekaman dan pencatatan satuan-satuan lingual, (c) penafsiran bentuk satuan-satuan lingual dan fungsinya dalam pelestarian lingkungan, (d) penyimpulan atau perampatan tentang pemakaian satuan-satuan lingual bahasa Jawa di Jawa Tengah.

\section{HASIL DAN PEMBAHASAN}

\section{Bentuk Lingual Pengungkap Kearifan Lokal dalam Melestarikan Lingkungan}

Bentuk satuan lingual yang digunakan untuk mengungkapkan kearifan lokal dalam melestarikan lingkungan berupa kata, frasa, kalimat, dan wacana. Bahasa dapat berperan dalam melestarikan lingkungan hidup. Hal ini sejalan dengan pendapat Kymlicka (2003) bahwa kondisi lingkungan hidup dapat juga dikaitkan dengan mutu dan kondisi lingkungan hidup kebahasaan yang multilingual, kemasyarakat yang multietnik, dan suasana kebudayaan yang juga semakin multikultural. Satuan lingual yang digunakan sebagai pengungkap kearifan lokal dalam melestarikan lingkungan oleh masyarakat tutur bahasa Jawa di Jawa Tengah meliputi satuan lingual kata, frasa, kalimat, dan wacana. Berikut akan dijelaskan bentuk-bentuk satuan lingual tersebut.

\section{Kata}

Kata adalah satuan bahasa yang memiliki satu pengertian atau kata adalah deretan huruf yang diapit oleh dua buah spasi dan mempunyai satu arti (Chaer, 1994:162). Tuturan yang digunakan untuk menyampaikan apa yang dirasakan atau dipikirkan oleh suatu masyarakat tutur bisa berupa kata. Satuan lingual ini dipakai oleh masyarakat tutur di Jawa Tengah untuk mengungkapkan kearifan lokal dalam melestarikan lingkungan karena bentuk ini lebih sederhana daripada satuan lingual yang lain. Pada (1) s.d. (4) berikut adalah satuan lingual berbentuk kata pengungkap kearifan lokal dalam melestarikan lingkungan.

1. disusruk 'cara mengambil rumput sehingga akarnya tidak ikut tercabut dengan harapan kelak dapat tumbuh kembali'

2. disesek atau diret 'dicabuti sampai ke akarnya sehingga rumput tidak mungkin tumbuh kembali',

3. diarit 'dipangkas menggunakan arit dan hanya bagian yang dapat dimanfaatkan saja, tujuannya agar rumput tersebut agar tetap hidup dan hasilnya dapat dimanfaatkan kembali',

4. dibedhol 'dicabut hingga akar agar mati karena termasuk dalam golongan gulma'.

Data (1) s.d (4) merupakan satuan lingual kata dalam bahasa Jawa yang digunakan untuk mengungkapkan kearifan lokal dalam pelestarian lingkungan masyarakat Kabupaten Blora. Kata tersebut merupakan kata kompleks, yakni kata yang mengalami proses morfologis, khususnya afiksasi (Verhaar, 1996:107). Kata tersebut sering dituturkan oleh masyarakat di Kabupaten Blora ketika mereka akan mengambil rumput untuk makanan ternak (biasanya sapi). Kata disusruk dipakai untuk menggambarkan cara mengambil rumput yang berguna, maksudnya rumput yang selalu dicari masyarakat Samin untuk makanan ternak mereka. Dengan cara disusruk, rumput yang dibutuhkan dapat diambil, tetapi akarnya tidak ikut tercabut dengan harapan kelak dapat tumbuh kembali. Dengan cara seperti ini, masyarakat 
memikirkan betul pelestarian tumbuhan (rumput) karena mereka tahu betul rumput jenis ini sangat dibutuhkan untuk makanan ternak mereka. Masyarakat tidak mengambil rumput seenaknya. Mereka sangat memahami dan bisa membedakan mana rumput yang berguna dan mana rumput yang tidak berguna.

Selain kata disusruk, dalam kaitannya dengan mengambil rumput, masyarakat juga mengenal kata disesek/diret. Kata ini dipakai untuk suatu pekerjaan mengambil rumput yang tidak berguna dengan cara dicabuti sampai ke akarnya sehingga rumput tidak akan tumbuh lagi. Masyarakat tahu betul, rumput yang sering digunakan untuk makanan ternak dan rumput yang tidak ada gunanya. Mereka sudah mempunyai pengetahuan bahwa rumput yang berguna sebagai makanan ternak harus dilestarikan, sebaliknya rumput yang tidak berguna tidak perlu dilestarikan, bahkan harus dimatikan karena hanya mengotori lingkungan sekitar. Dengan demikian, cara mengambilnya pun juga berbeda. Ini salah satu bentuk kearifan masyarakat penutur bahasa Jawa di Kabupaten Blora. Mereka percaya, siapa saja yang merusak lingkungan alam atau kosmos, ia akan dihukum oleh kekuatan Tuhan (Mumfangati, 2004:75). Dalam banyak kasus pada masyarakat yang lain, cara mengambil rumput antara yang dibutuhkan dengan yang tidak sama saja dengan cara dicabut sampai akarnya sehingga pelestarian tumbuhan itu tidak ada.

Seperti halnya masyarakat tutur bahasa Jawa di Kabupaten Blora, masyarakat tutur bahasa Jawa di daerah lain di Jawa Tengah ini juga mengenal satuan lingual lain yang digunakan untuk menjelaskan perbedaan antara mengambil rumput yang dibutuhkan dengan mengambil rumput liar yang tidak dibutuhkan. Data yang dapat menjelaskan hal tersebut adalah kata diarit dan dibedhol. Satuan lingual kata diarit dipakai untuk melambangkan kegiatan 'rumput yang dipangkas menggunakan arit dan hanya bagian yang dapat dimanfaatkan saja, tujuannya agar rumput tersebut tetap hidup dan hasilnya dapat dimanfaatkan kembali'. Adapun satuan lingual kata dibedhol digunakan untuk melambangkan konsep dicabut hingga akar agar mati karena termasuk dalam golongan gulma. Data-data tersebut dikelompokkan dalam satuan lingual kata karena memiliki bentuk dan makna (Matthews, 1974:21).

\section{Frasa}

Frasa lazim didefinisikan sebagai satuan gramatikal yang berupa gabungan kata yang bersifat nonpredikatif, atau lazim juga disebut gabungan kata yang mengisi salah satu fungsi sintaksis di dalam kalimat (Chaer, 1994:222; Ramlan, 1986:142). Dalam mengungkapkan kearifan lokal untuk melestarikan lingkungan, masyarakat tutur bahasa Jawa di Jawa Tengah juga menggunanakan satuan lingual frasa. Data (5) dan (6) berikut adalah frasa pengungkap kearifan lokal.

5. gunung urip 'gunung itu hidup dan merupakan saudara bagi orang samin yang berwujud gunung sehingga harus dihormati',

6. watu urip 'batu itu hidup dan merupakan saudara bagi orang samin yang berwujud batu sehingga harus dihormati'.

Data tersebut merupakan satuan lingual frasa yang digunakan oleh masyarakat tutur bahasa Jawa di Jawa Tengah untuk mengungkapkan kearifan lokal berkaitan dengan pelestarian lingkungan sekitar. Satuan lingual gunung urip dan watu urip disebut frasa karena satuan itu terdiri atas dua kata yang bersifat nonpredikatif, artinya kedua kata tersebut dalam kalimat menduduki satu fungsi kalimat (Chaer, 1994:222). 
Data berupa frasa gunung urip dan watu urip merupakan satuan lingual yang digunakan oleh masyarakat di Kabupaten Blora untuk mengungkapkan kearifan lokal masyarakat setempat dan hubungannya dengan upaya melestarikan lingkungan. Ketiga data tersebut digolongkan dalam satuan lingual frasa karena data-data tersebut terdiri atas dua kata yang menduduki satu fungsi dalam kalimat. Data gunung urip terdiri atas kata gunung dan urip yang memiliki makna gramatikal 'gunung itu hidup dan merupakan saudara bagi orang Samin yang berwujud gunung sehingga harus dihormati'. Data watu urip terdiri atas dua kata, yakni kata watu dan urip yang memiliki makna gramatikal 'batu itu hidup dan merupakan saudara bagi orang samin yang berwujud batu sehingga harus dihormati'. Masyarakat Samin di Kabupaten Blora menganggap bahwa gunung dan batu itu selalu hidup dan menjadi teman/saudara masyarakat Samin. Hal ini merupakan bentuk penghormatan masyarakat Samin terhadap segala hal yang berada di lingkungan mereka. Mereka mempersepsi mengenai lingkungan alam adalah semua isi alam raya baik manusia, binatang, dan tumbuhtumbuhan yang harus dijaga kelestariannya (Mumfangati, 2004:76). Masyarakat Samin dikenal sebagai masyarakat yang sangat dekat dan menghargai lingkungan sekitar. Dengan keadaan semacam itu, masyarakat Samin akan selalu menjaga dan memelihara kelestarian lingkungan mereka.

\section{Kalimat}

Kalimat adalah satuan bahasa terkecil, dalam wujud lisan atau tulisan, yang mengungkapkan pikiran yang utuh (Alwi dkk, 1998:311). Dalam wujud lisan, kalimat diucapkan dengan suara naik turun dan keras lembut, disela jeda, dan diakhiri dengan intonasi akhir yang diikuti oleh kesenyapan yang mencegah terjadinya perpaduan atau asimilasi bunyi ataupun proses fonologis lainnya. Dalam wujud tulisan berhuruf latin, kalimat dimulai dengan huruf kapital dan diakhiri dengan tanda titik (.), tanda tanya (?), atau tanda seru (!). Selain kata dan frasa, satuan lingual yang juga digunakan oleh masyarakat tutur untuk mengungkapkan kearifan lokal dalam melestarikan lingkungan adalah kalimat. Data (7), (8), dan (9) adalah kalimat pengungkap kearifan lokal.

7. Nandur iku kudu ngopeni, dadi sapa wae sing nandur uwit ya kudu ngopeni "untuk setiap orang yang sudah menanam tumbuhan atau mempunyai tumbuhan harus dirawat'

8. Aja nggrathili ramban nek mlaku mundhak korengen. 'dilarang menyakiti tumbuhan yang hidup di pinggir jalan karena berakibat membuat badan korengan jika melakukannya'

9. Aja nglarani kodhok mundhak lambene suwing. 'dilarang menyakiti katak karena berakibat membuat mulut sumbing'

Data tersebut merupakan satuan lingual berupa kalimat yang digunakan oleh masyarakat tutur bahasa Jawa di Jawa Tengah untuk mengungkapkan kearifan lokal tentang pelestarian lingkungan. Data-data tersebut dikategorikan sebagai satuan lingual kalimat karena data tersebut merupakan satuan lingual yang menyatakan pikiran yang lengkap. Di samping itu, data-data tersebut juga sudah mempunyai intonasi final.

Data berupa kalimat nandur iku kudu ngopeni, dadi sapa wae sing nandur uwit ya kudu ngopeni merupakan ajaran yang disampaikan secara lisan agar masyarakat memiliki tanggung jawab untuk merawat dan menjaga seluruh tanaman yang sudah ditanam. Tanaman tersebut membutuhkan perawatan supaya hidupnya terjaga dan memberi hasil yang 
maksimal. Tanaman tidak bisa tumbuh sendirian tanpa ada campur tangan manusia. Kalau pun bisa tumbuh, maka dapat dipastikan tumbuhnya tanaman tersebut tidak maksimal dan mungkin tidak akan memberi hasil yang memuaskan.

Data berupa kalimat aja nggrathili ramban nek mlaku mundhak korengen merupakan perintah agar masyarakat tidak mengganggu tumbuhan karena tumbuhan termasuk makhluk hidup yang perlu dijaga dan dilestarikan. Dengan mengganggu atau merusak tanaman, maka akan menyakiti tanaman tersebut. Di samping itu juga akan merusak lingkungan hidup. Para sesepuh mempunyai kearifan lokal tersendiri dalam menjaga lingkungan. Salah satunya dengan cara menghubungkan larangan tersebut dengan penyakit. Sebenarnya tidak ada relevansinya antara merusak tanaman dengan penyakit kulit. Namun. para sesepuh mengaitkan kedua hal tersebut agar masyarakat takut dan tidak merusak tanaman yang ada di sekitar kita. Tujuan utamanya tentu agar lingkungan termasuk tanaman tetap terjaga dengan baik.

Sementara itu, data kalimat aja nglarani kodhok mundhak lambene suwing juga berupa perintah agar tidak membunuh katak sembarangan. Katak termasuk binatang yang mestinya juga harus dilestarikan. Biasanya anggota masyarakat terutama yang masih berusia muda sering sulit untuk diberi tahu agar jangan membunuh binatang semaunya, meskipun binatang itu kelihatannya tidak berguna. Oleh karena itu, para sesepuh memiliki cara yaitu dengan mengubungkan larangan membunuh binatang dengan penyakit sumbing. Sebenarnya tidak ada relevansinya membunuh katak dengan penyakit sumbing. Maksud di balik tuturan itu sebenarnya para sesepuh berkeinginan untuk menjaga lingkungan, baik tumbuhan maupun binatang agar tidak dirusak.

\section{Wacana}

Yang dimaksud wacana adalah rentetan kalimat yang berkaitan yang menghubungkan proposisi yang satu dengan proposisi yang lain dan membentuk kesatuan (Alwi, 1998:419). Di samping itu, wacana juga merupakan satuan bahasa yang lengkap sehingga dalam hierarki gramatikal merupakan satuan gramatikal tertinggi dan terbesar. Sebagai satuan bahasa yang lengkap, dalam wacana itu terdapat konsep, gagasan, pikiran atau ide yang utuh yang bisa dipahami oleh pembaca (dalam wacana tulis) atau pendengar (dalam wacana lisan) tanpa keraguan apa pun. Sebagai satuan gramatikal tertinggi dan terbesar berarti wacana itu dibentuk dari kalimat atau kalimat-kalimat yang memenuhi persyaratan gramatikal dan persyaratan kewacanaan lainnya. Data (10), (11), dan (12) adalah wacana pengungkap kearifan lokal.

10. Kandane nek arep nandur uwit, sing wenang wujude niku bapa kuasa, ibu pertiwi, banyu, angin, geni. Nyuwun tulung niki titip dadipun uripaken supadas sae 'untuk menanam pohon harus izin dulu kepada pemilik tempat tersebut yang seolah-olah ada yang mempunyai seperti halnya berdoa agar yang ditanam tumbuh dengan subur dan baik'

11. Nandur iku kudu ngopeni, dadi sapa wae sing nandur uwit ya kudu ngopeni. Carane pripun nggih dipupuk, disiram 'untuk setiap orang yang sudah menanam tumbuhan atau mempunyai tumbuhan harus dirawat', dan

12. Saben setaun sepindhah yaiku gas desa, tembung saking gas iku tegas desa iku rakyate. Maksude gas desa yaiku ajeng ndamel kajat, desa ngeruwohi bumi ngopeni bumi 'setiap tahun diadakan kegiatan gas desa. Gas desa yaitu ritual yang dilakukan 
setahun sekali dengan menggunakan berbagai hasil panen yang dimaksudkan untuk menghormati bumi dan untuk mengajak warga agar menjaga bumi'.

Data tersebut merupakan satuan lingual berwujud wacana yang digunakan oleh masyarakat tutur bahasa Jawa di Jawa Tengah untuk mengungkapkan kearifan lokal tentang pelestarian lingkungan. Data-data tersebut dikategorikan sebagai satuan lingual wacana karena data tersebut merupakan satuan lingual yang terdiri atas beberapa kalimat berdasarkan konteks tertentu. Di samping itu, kalimat-kalimat yang membangun wacana tersebut saling padu antara satu dengan yang lainnya (Sumarlam 2003:15).

Data berupa wacana kandane nek arep nandur uwit, sing wenang wujude niku bapa kuasa, ibu pertiwi, banyu, angin, geni. Nyuwun tulung niki titip dadipun uripaken supadas sae menyampaikan pesan bahwa untuk menanam pohon harus izin dulu kepada pemilik tempat tersebut yang seolah-olah ada yang mempunyai seperti halnya berdoa agar yang ditanam tumbuh dengan subur dan baik. Masyarakat di Kabupaten Blora percaya bahwa lingkungan di sekitar yang terdiri atas langit, bumi, air, angin, dan api sangat dekat dengan kehidupan mereka. Oleh karena itu, segala sesuatu yang akan dilakukan oleh masyarakat tersebut selalu dikaitkan dengan alam dan isinya. Seperti halnya ketika masyarakat tersebut akan menanam pohon terlebih dahulu meminta izin kepada alam yang dianggap memiliki tanaman tersebut. Hal ini merupakan salah bentuk kearifan lokal masyarakat dalam melestarikan lingkungan.

Data berupa wacana nandur iku kudu ngopeni, dadi sapa wae sing nandur uwit ya kudu ngopeni. Carane pripun nggih dipupuk, disiram merupakan bentuk kearifan lokal masyarakat untuk selalu menjaga dan memelihara alam dan isinya. Pada data tersebut dikatakan bahwa kalau menanam tumbuhan wajib untuk memelihara. Ajaran tersebut mengajarkan kepada masyarakat untuk selalu bertanggung jawab ketika melakukan suatu tindakan. Dalam konteks itu, yang dilakukan oleh masyarakat adalah menanam. Dengan demikian, masyarakat tidak hanya menanam saja, tetapi yang lebih penting bagaimana memelihara dan merawat tanaman tersebut supaya tumbuh subur dan menghasilkan sesuatu yang bermanfaat bagi masyarakat.

Adapun data berikutnya berupa wacana saben setaun sepindhah yaiku gas desa, tembung saking gas iku tegas, desa iku rakyate. Maksude gas desa yaiku ajeng ndamel kajat, desa ngeruwohi bumi ngopeni bumi. Tuturan yang berupa wacana tersebut merupakan bentuk kearifan lokal masyarakat setempat dalam menghormati lingkungan. Masyarakat Kabupaten Blora - khususnya masyarakat Samin — selalu mengadakan kegiatan gas desa dalam rangka memelihara dan melestarikan bumi dan isinya. Mereka percaya bahwa lingkungan harus dirawat karena telah memberikan hasil yang melimpah bagi masyarakat tersebut selama satu tahun (Mumfangati 2004:78). Maka mereka selalu mensyukuri apa yang telah didapatkan dari alam tersebut.

\section{Fungsi Satuan Lingual sebagai Pengungkap Kearifan Lokal dalam Melestarikan Lingkungan pada Masyarakat Tutur Bahasa Jawa}

Pada bagian terdahulu telah dijelaskan bentuk satuan-satuan lingual pengungkap kearifan lokal berkaitan dengan pelestarian lingkungan. Satuan-satuan lingual tersebut digunakan oleh masyarakat tutur tentu ada tujuannya. Tujuan penggunaan satuan-satuan lingual tersebut berkenaan dengan fungsi digunakannya satuan-satuan lingual. Menurut data yang dianalisis, ada tiga tujuan masyarakat menggunakan satuan lingual sebagai pengungkap 
kearifan lokal dalam melestarikan lingkungan pada masyarakat tutur bahasa Jawa di Jawa Tengah, yakni memberi nama, memerintah, doa, dan sebagai ajaran berbentuk sesorah.

\section{Memberi Nama}

Seperti yang kita ketahui bahwa fungsi bahasa adalah alat komunikasi. Dalam realitas berbahasa, bahasa memang tidak bisa dilepaskan dengan faktor sosial dan budaya masyarakat penuturnya. Oleh karena itu, perwujudan suatu bahasa sangat dipengaruhi oleh latar belakang sosial budaya masyarakat penutur bahasa tersebut. Hal ini sejalan dengan apa yang disampaikan oleh Pastika (2005:103) bahwa peran bahasa sangat dominan dalam kehidupan manusia karena bahasa tidak hanya menjadi bagian dari kebudayaan manusia, tetapi juga menjadi penentu dari perkembangan kebudayaan itu sendiri.

Hal yang akan disampaikan kepada orang lain adalah apa yang dipikirkan/dirasakan atau konsep. Adapun hal yang dipakai untuk melambangkan adalah bunyi bahasa. Dengan demikian, bahasa adalah lambang yang berwujud bunyi bahasa (Lyons, 1977:37). Proses pelambangan suatu konsep ini sama artinya manusia memberi nama suatu konsep tertentu.

Kearifan lokal yang dimiliki oleh masyarakat tutur bahasa Jawa di Jawa Tengah yang berkaitan dengan pelestarian lingkungan bisa berwujud kata, frasa, kalimat, dan wacana. Satuan-satuan lingual itu terutama yang berwujud satuan lingual kata dan frasa ada yang memiliki fungsi untuk memberi nama sutu konsep. Tiga bentuk lingual, yakni diarit, raja kaya, dan gunung urip dapat memperjelas fungsi tersebut. Dengan pemberian nama tersebut, masyarakat kemudian menyebut suatu konsep tertentu dengan lambang bunyi tersebut. Data (13), (14), dan (15) dapat menerangkan fungsi memberi nama tersebut.

\section{3. diarit $^{1}$ \\ 14. raja kaya \\ 15. gunung urip ${ }^{2}$}

Data-data tersebut merupakan satuan lingual berupa kata dan frasa yang digunakan untuk mengungkapkan kearifan lokal masyarakat setempat berkaitan dengan pelestarian lingkungan. Data-data tersebut merupakan nama suatu konsep benda atau kegiatan yang dipakai oleh masyarakat setempat untuk menyebut konsep benda atau kegiatan yang bersangkutan. Data berupa kata diarit untuk memberi nama suatu kegiatan memangkas menggunakan arit dan hanya bagian yang dapat dimanfaatkan saja, tujuannya agar rumput tersebut agar tetap hidup dan hasilnya dapat dimanfaatkan kembali, raja kaya untuk memberi nama dan menghormati binatang karena binatang termasuk makhluk hidup. Di samping itu, binatang telah memberi keuntungan bagi para petani, sehingga merupakan investasi kekayaan bagi yang memilikinya. Selain itu, ada frasa gunung urip yang digunakan untuk menmberi nama dan menyebut bahwa gunung itu hidup dan merupakan saudara bagi orang samin yang berwujud gunung sehingga harus dihormati.

\section{Memerintah/Menasihati}

Dalam budaya Jawa dikenal adanya sesorah, yakni ajaran yang disampaikan secara turun-temurun dari generasi ke generasi. Ajaran tersebut disampaikan secara lisan. Masyarakat Jawa sangat menghormati dan mempercayai ajaran-ajaran tersebut. Dalam ajaran yang berbentuk sesorah tersebut ada beberapa yang disampaikan dalam bentuk perintah.

\footnotetext{
${ }^{1}$ Data sudah muncul pada bagian bentuk lingual pengungkap kearifan lokal

${ }^{2}$ Data udah muncul pada bagian bentuk lingual pengungkap kearifan lokal
} 
Perintah tersebut biasanya berisi saran atau larangan untuk tidak melakukan sesuatu yang menjadi pantangan bagi masyarakat Jawa yang ada di Jawa Tengah. Perintah yang diwujudkan dengan kalimat perintah tersebut disampaikan masyarakat Jawa golongan tua kepada masyarakat Jawa golongan muda. Perhatikan contoh (16), (17), dan (18) berikut.

16. aja diteres

17. aja nggrathili ramban nek mlaku mundhak korengen

18. aja nglarani kodhok mundhak lambene suwing

Data tersebut merupakan satuan lingual berbentuk kalimat yang dipakai untuk mengungkapkan kearifan lokal masyarakat tutur bahasa Jawa di Jawa Tengah untuk melestarikan lingkungan. Kalau diperhatikan, data-data tersebut berbentuk kalimat-kalimat perintah yang digunakan untuk melarang atau memberi saran untuk tidak melakukan sesuatu yang menjadi pantangan bagi masyarakat setempat. Secara lengkap, data tersebut adalah aja diteres, yakni suatu kalimat yang berisi kearifan lokal agar masyarakat tidak mengelupasi kulit dan merusak pohon bambu semaunya, aja nggrathili ramban nek mlaku mundhak korengen, yakni suatu kalimat yang berisi kearifan lokal untuk tidak menyakiti tumbuhan yang hidup di pinggir jalan, aja nglarani kodhok mundhak lambene suwing, yakni suatu kalimat perintah yang berisi kearifan lokal untuk tidak menyakiti katak, meskipun kemudian dikaitkan dengan akibat kalau menyakiti katak yakni bibir sumbing. Dengan demikian, datadata tersebut berisi perintah untuk tidak melakukan sesuatu yang menjadi larangan atau pantangan suatu masyarakat. Dengan kata lain, masyarakat tutur bahasa Jawa di Jawa Tengah menggunakan kalimat-kalimat tersebut dengan tujuan untuk memerintah agar masyarakat tidak melakukan sesuatu yang menjadi larangan atau pantangan masyarakat yang bersangkutan

\section{Memanjatkan Doa}

Dari data penelitian, terdapat satuan lingual berbentuk kalimat yang dipakai untuk mengungkapkan kearifan lokal masyarakat tutur bahasa Jawa di Jawa Tengah berkaitan dengan pelestarian lingkungan. Satuan lingual berbentuk kalimat tersebut digunakan dengan tujuan sebagai doa. Data ini ditemukan pada masyarakat tutur bahasa Jawa di Kabupaten Blora, yakni masyarakat Samin. Bagi masyarakat Samin, doa adalah ungkapan hati yang ditujukan bagi Sang Pencipta melalui segala yang ada di lingkungan mereka. Masyarakat Samin dikenal sebagai pengikut agama Adam. Adam merupakan perwujudan "ucapan" dan diwujudkan dengan aktivitas yang baik (Rosyid 2008:196). Munculnya istilah Adam sebagai bukti pemahaman masyarakat Samin sebagai nama manusia pertama yang diciptakan Tuhan di sunia ini, sedangkan kata agama bukan berarti tradisi tersebut menjadi agama, melainkan lebih bermakna ugeman atau pegangan hidup yang bermuatan etika hidup menjadi kepercayaan yang dipegang erat.

Bagi masyarakat Samin, praktik berdoa memiliki arah dan tujuan dari diri kepada Tuhan penguasa tunggal (Yai) dengan mengucapkan becik apik sak rinane, sak wengine 'sukses di waktu siang dan malam hari', bumi aji aku jaman 'menempati bumi dan berteduh zaman' dilaksanakan di rumah, setiap saat membutuhkjan dengan praktik mengheningkan hati dan menundukkan kepala tanpa menengadahkan kedua tangan (Rosyid 2008:200). Selain doa tersebut, masyarakat Samin ketika berdoa juga selalu menyebut hal-hal yang dijumpai di sekitarnya. Contoh data: (1) Iki bumi, iki kayu iki arep tak kanggekke, (2) Kandane nek arep 
nandur uwit, sing wenang wujude niku bapa kuasa, ibu pertiwi, banyu, angin, geni. Nyuwun tulung niki titip dadipun uripaken supadas sae.

Data tersebut merupakan satuan lingual berbentuk kalimat dan wacana yang digunakan masyarakat Samin di Kabupaten Bora untuk mengungkapkan kearifan lokal berkaitan dengan pelestarian lingkungan. Data iki bumi, iki kayu iki arep tak kanggekke berfungsi sebagai doa dan memohon izin kepada Tuhan dengan menyebut nama bumi ketika mengambil barang yang berada di alam. Masyarakat Samin memiliki ajaran bahwa ketika akan memanfaatkan alam dan isinya, mereka selalu berdoa dengan cara menyebut dan minta izin kepada alam sekitar terlebih dahulu, Adapaun data berikutnya berupa Kandane nek arep nandur uwit, sing wenang wujude niku bapa kuasa, ibu pertiwi, banyu, angin, geni. Nyuwun tulung niki titip dadipun uripaken supadas sae. Tuturan tersebut berbentuk wacana. Masyarakat Samin di Kabupaten Blora menggunakan tuturan tersebut dengan fungsi sebagai doa dan permohonan izin kepada pemilik tempat tersebut yang seolah-olah ada yang mempunyai agar tanaman tumbuh dengan subur. Doa itu dilakukan ketika masyarakat Samin akan menanam pohon. Meskipun demikian, masyarakat Samin bukanlah penyembah brahala atau dhanyang. Mereka juga tidak percaya akan jin, setan, hantu, dan sejenisnya sehingga tidak mempunyai rasa takut akan hal-hal yang menurut umum angker, wingit, dan sebagainya (Mumfangati, 2004:49).

\section{Mengajarkan Pandangan Hidup secara Lisan (Sesorah)}

Sesorah adalah cara menyampaikan ajaran masyarakat Samin yang disampaikan turuntemurun secara lisan (Widodo, 2000:16). Ajaran ini sangat ditaati oleh masyarakat Samin disampaikan oleh sesepuh masyarakat ke generasi muda. Ajaran ini pertama kali disampaikan oleh sesepuh sekaligus pemimpin masyarakat Samin, yakni Samin Surosentiko. Ajaran ini disampaikan secara lisan karena masyarakat Samin belum mengenal tulisan dan tidak bisa baca tulis. Bahkan sampai sekarang pun yang bisa baca tulis sangat terbatas karena bagi masyarakat Samin sekolah formal itu dilarang. Konsep sekolah bagi mereka adalah menimba ilmu dari orang tuanya dengan cara menerima ajaran yang disampaikan secara lisan (sesorah). Dalam data penelitian ini terdapat data berupa satuan lingual kalimat yang digunakan untuk mengungkapkan kearifan lokal berkaitan dengan pelestarian lingkungan dan berfungsi sebagai ajaran berbentguk sesorah. Data yang dapat diamati: (1) Nandur iku kudu ngopeni, dadi sapa wae sing nandur uwit ya kudu ngopeni, (2) Wong rawat kuwe cawangane iman.

Kedua data tersebut dituturkan oleh masyarakat Samin dengan fungsi sebagai ajaran berbentuk sesorah. Data berwujud kalimat Nandur iku kudu ngopeni, dadi sapa wae sing nandur uwit ya kudu ngopeni merupakan ajaran yang berbentuk sesorah disampaikan oleh para sesepuh kepada orang yang lebih muda untuk selalu merawat dan memelihara tanaman ketika mereka menanam pohon yang bermanfaat. Adapun data berupa kalimat Wong rawat kuwe cawangane iman dituturkan oleh sesepuh masyarakat di Kabupaten Tegal sebagai ajaran dan memberi nasihat bahwa membersihkan lingkungan dari sampah yang berserakan adalah sebagian dari iman maksudnya adalah sebagai manusia yang beriman kita harus menjaga kebersihan lingkungan agar terhindar dari penyakit dan bencana. Dengan demikian, dari temuan data tersebut jelas bahwa terdapat satuan lingual berbentuk kalimat yang mengungkapkan kearifan lokal masyarakat dalam upaya melestarikan lingkungan dan difungsikan sebagai ajaran dan disampaikan dengan cara sesorah. 


\section{SIMPULAN DAN SARAN}

Berdasarkan analisis data tersebut, dapat disimpulkan dua hal berikut. Pertama, bentuk satuan lingual yang digunakan untuk mengungkapkan kearifan lokal dalam melestarikan lingkungan pada masyarakat tutur bahasa Jawa di Jawa Tengah meliputi satuan lingual kata, frasa, kalimat, dan wacana. Kedua, fungsi satuan lingual yang digunakan oleh masyarakat tutur bahasa Jawa di Jawa Tengah untuk mengungkapkan kearifan lokal berkaitan dengan upaya pelestarian lingkungan meliputi fungsi-fungsi (i) menamai, (ii) memerintah/menasihati, (iii) memanjatkan doa, dan (iv) mengajarkan pandangan hidup secara lisan (sesorah).

Saran yang dapat disampaikan adalah sebagai berikut. Pertama, masyarakat perlu mempertahankan kearifan lokal tiap-tiap daerahnya karena kearifan lokal merupakan kekayaan budaya yang tidak ternilai. Kedua, masyarakat perlu memelihara dan merawat lingkungan di sekitar tempat tinggal mereka karena lingkungan yang asri dan terawat akan memberikan keuntungan kenyamanan dalam hidup sehari-hari. Ketiga, salah satu kearifan lokal yang dimiliki oleh masyarakat di Jawa Tengah adalah kearifan lokal yang berbentuk satuan-satuan lingual. Satuan-satuan lingual ini digunakan oleh masyarakat tutur dalam upaya untuk melestarikan lingkungan. Oleh karena itu, masyarakat di Jawa Tengah perlu mempertahankan dan melestarikan kearifan lokal berbentuk satuan lingual dalam bahasa Jawa agar generasi muda lebih memahami bahasa Jawa.

\section{DAFTAR RUJUKAN}

Alwi, H., Dardjowidjojo, S., Lapoliwa, H., \& Moeliono, A.M. 1998. Tata Bahasa Baku Bahasa Indonesia. Jakarta: Balai Pustaka.

Casson, R.W (Ed.) 1981. Language, Culture, and Cognition: Anthropological Perspectives. New York: Macmillian Publishing Co.Inc.

Chaer, A. 1994. Linguistik Umum. Jakarta : Rineka Cipta

Endraswara, S. 2010. Falsafah Hidup Jawa, Menggali Mutiara Kebijakan dari Intisari Filsafat Kejawen. Yogyakarta: Cakrawala.

Kymlicka, W. 2003. Kewargaan Multikultural. Terjemahan Edlina Haffmini Eddin. Jakarta: LP3ES.

Liliweri, A. 2002. Makna Budaya dalam Komunikasi Antarbudaya. Yogyakarta: LKiS.

Lyons, J. 1977. Semantics Volume 1. Cambridge: Cambridge University Press.

Mahsun. 2005. Konsep Ruang dalam Bahasa Mbojo dan Kaitannya dengan Cara Pandang Masyarakat Penuturnya. Jurnal Linguistik Indonesia, 23(1), Februari 2005, hlm. 81-88

Matthews, P.H. 1974. Morphology, An Introduction to The Theory of Word Sructure. Cambridge: Cambridge University Press.

Miles, M.B dan Huberman, A.M. 1992. Analisis Data Kualitatif. Terjemahan Tjetjep Rohendi Rohidi. Jakarta: Universitas Indonesia.

Mumfangati, T., Murniatmo, G., Sunjata, IW.P., Sumarsih, S., Susilantini, E., Ariani, C. 2004. Kearifan Lokal di Lingkungan Masyarakat Samin, Kabupaten Blora, Propinsi Jawa Tengah. Yogyakarta: Kementerian Kebudayaan dan Pariwisata.

Pastika, I.W. 2005. Linguistik Kebudayaan: Konsep dan Model. Jurnal Linguistika, 12(2), Maret 2005, hlm. 102-112.

Ramlan, M. 1986. Ilmu Bahasa Indonesia Sintaksis. Yogyakarta: CV Karyono. 
Rosyid, M. 2008. Samin Kudus: Bersahaja di Tengah Asketisme Lokal. Yogyakarta: Pustaka Pelajar.

Sudaryanto. 1993. Metode dan Aneka Teknik Analisis Bahasa, Pengantar Penelitian Wahana Kebudayaan secara Linguistis. Yogyakarta: Duta Wacana University Press.

Sumarlam (Ed.). 2003. Teori dan Praktik Analisis Wacana. Surakarta: Pustaka Cakra.

Verhaar, J.W.M. 1996. Asas-asas Linguistik Umum. Yogyakarta: Gadjah Mada University Press.

Widodo, A. 2000. Untuk Hidup Tradisi Harus Mati. Basis, $49(09$ \& 10), September-Oktober 2000, hlm. 14-23. 